\title{
Socio-environmental tensioning in coastal communities: an interdisciplinary study in the mangroves of southern Bahia
}

\author{
Júlio Augusto de Castro Pellegrini \\ Elza Maria Neffa Vieira de Castro \\ Krishna Neffa Vieira de Castro \\ Mário Luiz Gomes Soares
}

${ }^{I}$ PROOCEANO - Serviço Oceanográfico e Ambiental, Rio de Janeiro, Rio de Janeiro, Brasil.

${ }^{\text {II }}$ Universidade do Estado do Rio de Janeiro, Rio de Janeiro, Rio de Janeiro, Brasil.

D III Universidade do Estado do Rio de Janeiro, Rio de Janeiro, Rio de Janeiro, Brasil.

IV Universidade do Estado do Rio de Janeiro, Rio de Janeiro, Rio de Janeiro, Brasil.

\begin{abstract}
This article analyzes the connections between environmental vulnerability of the mangrove forests of Garapuá (Bahia, Brazil) and the social vulnerability of the shellfish colectors and fishermen, from the tensions inflicted with the insertion of the oil industry. From an interdisciplinary perspective, it presents the interpretation of complex phenomena and integrated management of the environment, incorporating the opening of the human spirit to the vision of totality. The seizure of the dialectical logic of local socio-environmental processes was based on the characterization of mangrove forests, using quantitative methods, and integration with the research process through field observations and semi-structured interviews, from the point of view of the qualitative approach. The article aimed to demonstrate that interdisciplinary analysis strengthens the debate in different segments of society (companies, environmental agencies, nongovernmental organizations, universities, communities, etc.) and, consequently, tends to favor the transformation of the socio-environmental reality experienced by social groups without decision power.
\end{abstract}

Keywords: Mangrove; Phytosociology; Oil industry; Socio-environmental vulnerability; Interdisciplinarity.

São Paulo. Vol. 23, 2020

Original Article

DOI: http://dx.doi.org/10.1590/1809-4422asoc20180175r3vu2020L5AO 


\section{Introduction}

This paper analyzes, from an interdisciplinary perspective, the existing connections between the environmental vulnerability of the mangrove forests that make up the coastal space of the Garapuá cove, Tinharé island, municipality of Cairu, Southern Bahia (figure 1), and the social vulnerability of the inhabitants of this cove, based on the tension inflicted with the insertion of the oil industry, given the difficulty of this community to absorb the effects of the transformations occurred in the environment, which translates into the implementation of productive alternative practices to the risk that is being submitted.

Figure 1 - Map of Tinharé and Boipeba Islands (Bahia, Brazil).

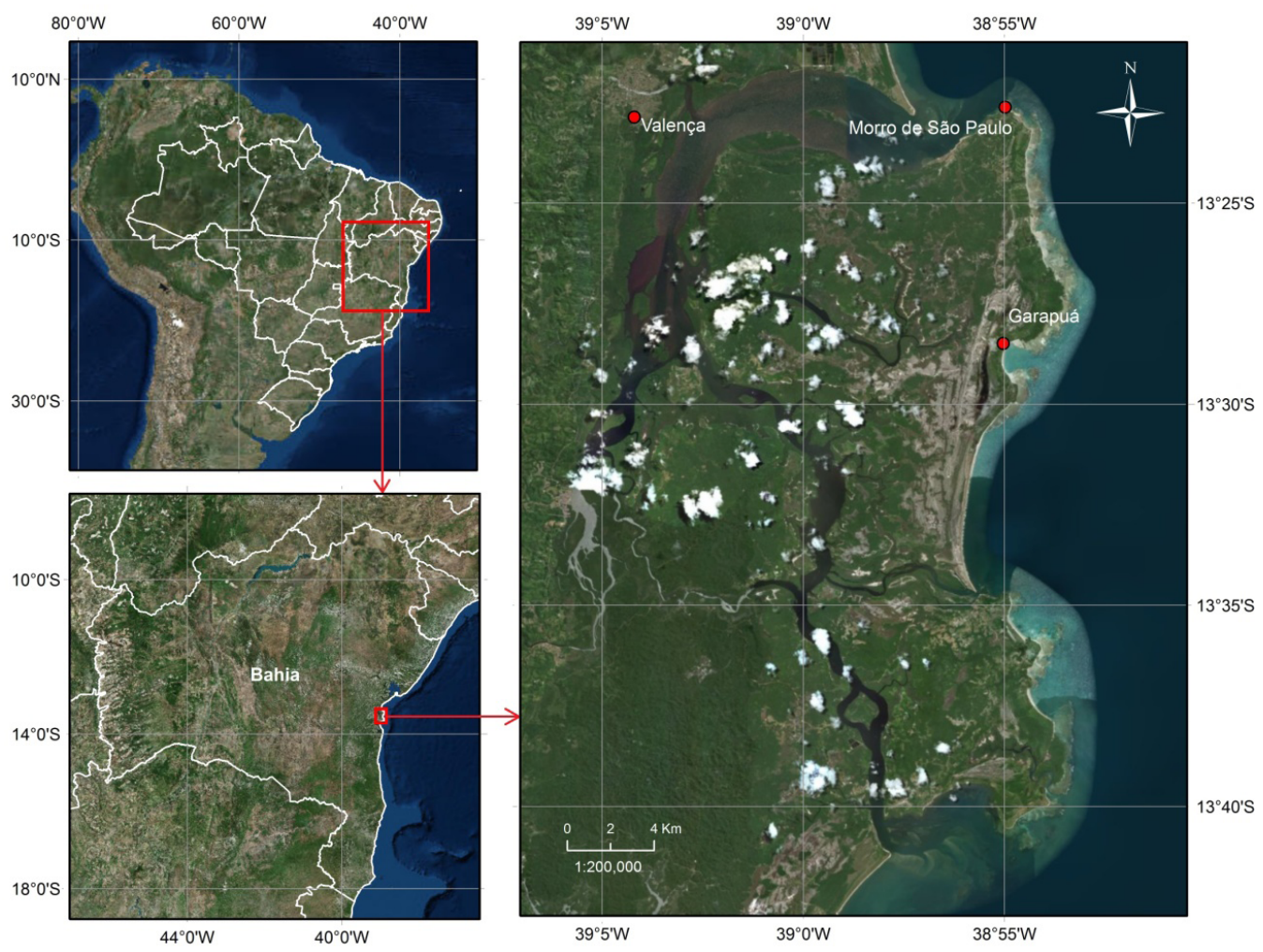

Source: The author, 2019. 
The Garapuá village is located in the eastern portion of Tinharé island (figure 1), one of the three main islands in the municipality archipelago of Cairu (Bahia). It is home to around seven hundred residents who live primarily from fishing and shoreline fishing (shellfish gathering), mainly from mollusc Lucina pectinata ("Lambreta"), found in abundance in mangroves, along with other bivalve shellfish, crabs, blue land crab and soft crabs.

Since 2007, a significant portion of the natural gas produced in the state of Bahia comes from coastal waters near the island. With the arrival of the oil industry, the need to study these ecosystems from a perspective that could envision, both the physical space, as well as social relations, knowledge, traditional productive practices exercised in the seas and mangroves, that conforms a landscape configured as an integrated system, has arisen.

The analysis of mangrove forests required knowledge about the structural characteristics of the vegetation to establish reference standards on them. This characterization demanded the adoption of quantitative research methods. Based on this survey, a methodology for classifying forests was elaborated which, being based on structural development and aspects of its architecture, allowed the definition of the environmental vulnerability of each portion of the mangrove forest (PELLEGRINI et al., 2009). Observing the biological-ecological aspects, risks of impacts related to the oil industry's capacity to increase the vulnerability of this ecosystem were detected.

By investigating the environment, the strong relationship of the local community with the forest was evidenced as a locus of income generation and construction of the social imaginary.

The shoreline shellfish gathering activity is predominantly carried out by women, with young people and men standing out in fishing practices. It is not uncommon for families to survive and support themselves from shoreline shellfish gathering activities, whose commercialization is done in the city of Valença or directly in Salvador (the capital of the state of Bahia) especially "Lambreta", which is only possible due to the traditional knowledge that these communities have developed regarding the environments that surround them.

Although this study is limited to artisanal shoreline fisherwomen (gatherers), it is essential to highlight that the perception of risk extends to other local labour categories, especially those directly connected to the sea, as in the case of fishers.

A socio-environmental vulnerability was identified when, in mid-2005, the small community felt tensioned by the implementation of a gas exploration/production platform, considering that the activities of shoreline shellfish gathering and fishing, developed in the locality of Garapuá, involve the vast majority of inhabitants and constitute, along with tourism, one of the main bases of economic support of the place.

In this context, the question of the conservation of mangrove forests is not restricted to the knowledge (recognition) of their uniqueness, but, also, there is an identity built by the community based on the relationship established in and with the forest that gives rise to values, interwoven behaviours and ways of life that, in a way, are threatened. 
These findings led to the assumption that the advance of economic and political sectors involved in potentially polluting ventures maximizes factors that contribute to the increase in environmental and social vulnerability, mainly when it deals with economically low-income population groups.

\section{Principles of the interdisciplinary methodological approach and research procedures}

The deepening of the existing links between environmental vulnerability and social vulnerability demanded an interdisciplinary analysis, considering that the construction of the representation of the totality of reality requires the integration of knowledge that privileges contextualization and procedural. The basis of the interdisciplinary methodological approach does not rule out the specific analyzes of each field of expertise, but, by interweaving its peculiarities, it incorporates scientific knowledge not from an idea of harmony, but from the existence of "a common axiomatic of groups of related disciplines", which is not characterized as a discipline placed at a higher hierarchical level, but as a theoretical-methodological reference scheme developed by scientists from different areas (ALVARENGA et al., 2011).

From 2002 to 2010, field works were carried out in the mangroves, in the Cairu, Morro de São Paulo, Barra dos Carvalhos, Batateira and Garapuá villages, in the restingas, in the coconut groves, on the beaches, in the reefs, in the estuary, in the rivers and at sea, and made it possible to apprehend the logic of local socioenvironmental processes through the narrowing of the relationship between theory and practice. Throughout this process, testimonies were collected from sixty-four (64) social actors through open and semi-structured interviews, conducted with public managers, priests, entrepreneurs and representatives of the Garapuá community (school principals and teachers, nursing technicians from the Local Health Care Unit, representative of the Colony of Fishermen and Farmers Z-55 of the Municipality of Cairu and of the Association of Residents and Friends of Garapuá, artisans, farmers and workers - street sweepers, police officers, tractor drivers, drivers, coconut collectors, servants, owners of inns, kiosks, boats, women, youth, the elderly and children, who were an essential source of socio-economic representations and of the symbolic aspects that determined the social imaginary of the inhabitants of Garapuá village. The testimonies revealed the socio-environmental vulnerability that is reflected in the different elements listed in the $2 \mathrm{nd}$ and $3 \mathrm{rd}$ paragraphs of the item of this article called "The oil industry and the "tensioning" of fishermen/womem shellfish gatherers of Garapuá".

The integration with the researched group was made from the perspective of the qualitative approach, in participant observations (MARTINS; THEÓPHILO, 2009; BRANDÃO, 1982) in the temporary coexistence with the daily activities and with the events considered relevant by the community, adopting an attitude opened to the spirit to different logics and to other ways of intuiting the necessary relations to face the tensions of the contemporary world.

Although different, the quantitative and qualitative methods are not mutually 
exclusive, being used in investigations that build more than one research object from the same theme, as is the case of the present study. The interaction of such approaches is possible when quantitative analyzes raise questions that can only be asked within qualitative principles or vice versa.

The interpretative approach research adopted in this case study records information, collected data and perceptions and proceeds to its organization and analysis using the procedures of discourse analysis (GIL, 2002), observation in field researches and interviews (GIL , 2009), by considering them the most suitable for the intended objective and the socialization of results.

The production and socialization of knowledge in the environmental field have been pointing out the need to adopt interdisciplinarity as an interpretative approach to complex phenomena, in an attempt to overcome the fragmentation of the sciences and the compartmentalized knowledge produced by them and to point out new ways of organization, production, diffusion and transfer of knowledge and practices capable of transforming the relationship between human beings and the environment that surrounds them and of which we are part of it. This need arises from the dialectical character of social reality, which is simultaneously one and diverse, and from the intersubjective nature of its apprehension by the subjects who have limits to understand its historical and complex character (MORIN, 2007). This character demands that, when defining an object of research for an analytical investigation of reality, the multiple determinations (social, cultural, economic, political, religious, etc.) that constitute it and the historical mediations that condition it is not abandoned or separated from the totality of which they are part since this reality is conceived as a concrete totality, that is, as "a structured whole in the course of development and self-creation" (KOSIK, 1976). There is no way to fragment it, to understand it, without mischaracterize it.

The composition of a panel of reciprocal interactions between social groups and the profiles of natural elements and conditions of the mangroves in southern Bahia aimed to expand the perception of the socio-environmental issue, visualizing the geographic, social, economic, political and technical-scientific factors, because this way of interpreting reality involves the complexity of socio-environmental relations, the contextualization of analyzes and the procedural dimension (LITTLE, 2006), which extend over the totality of social life and the way of thinking about this totality.

\section{The Garapuá mangrove forest: characteristics and vulnerabilities}

The mangrove area of approximately 150 hectares located in the eastern portion of the island, facing the open sea, has a unique status considering the entire Brazilian coast, given its direct association with reef formations that follow a typical pattern only in the Caribbean region and in some areas of the western portion of the Pacific Ocean and eastern Indian Ocean (STODDART, 1980). With the characterization of this ecosystem, it was possible to perceive that the degree of sensitivity of the forest was higher than that observed in adjacent estuarine regions, considering its dependence on reef formations, 
the type of substrate and the confinement status, as it is surrounded by sandy beaches, sand bars and reefs.

Starting from the recognition of the heterogeneity of the Garapuá mangrove forests, both in terms of the physical environment (for example, geomorphology, flood frequency by tides) that conditions their ecological characteristics, such as species composition, structural development and architecture of these forests, 12 types of mangrove forests were identified in the region (table 1). For this purpose, 52 sampling stations distributed throughout the mangrove forest were characterized, as described in Pellegrini et al. (2009) and Pellegrini (2010), based on methods adapted from Cintron \& Schaeffer-Novelli (1984).

Table 1 - Synthesis of Structural Types identified in the mangrove forests of Garapuá (Bahia, Brazil).

\begin{tabular}{|c|c|c|c|c|c|}
\hline $\begin{array}{l}\text { Development } \\
\text { Level }\end{array}$ & $\begin{array}{l}\text { Maxi- } \\
\text { mum }\end{array}$ & High & $\begin{array}{l}\text { Interme- } \\
\text { diate }\end{array}$ & $\begin{array}{l}\text { Twisted } \\
\text { Forests }\end{array}$ & Low \\
\hline Mean DBH $(\mathrm{cm})$ & $\begin{array}{c}29.9- \\
27.0\end{array}$ & $22.9-15.6$ & \multicolumn{2}{|c|}{$14.8-4.5$} & $3.1-1.6$ \\
\hline Mean Heigth (m) & $\begin{array}{c}21.2- \\
17.7 \\
\end{array}$ & $22.7-11.8$ & \multicolumn{2}{|c|}{$13.7-5.7$} & $4.7-2.4$ \\
\hline $\begin{array}{l}\text { Rhizophora } \\
\text { mangle } \\
\text { (dominant or } \\
\text { monospecific) }\end{array}$ & $\begin{array}{c}\text { Type } 1 \\
(12,13, \\
21,34, \\
35)\end{array}$ & $\begin{array}{c}\text { Type } 3 \\
(5,8,9,18, \\
20,22,26, \\
29,30,36, \\
39,40,48, \\
50,51)\end{array}$ & $\begin{array}{c}\text { Type } 6 \\
(14,15,19 \\
23,25,27 \\
28,38,42)\end{array}$ & $\begin{array}{c}\text { Type } 7 \\
(3,37,41 \\
43)\end{array}$ & $\begin{array}{c}\text { Type } 11 \\
(16,24,33)\end{array}$ \\
\hline $\begin{array}{l}\text { Avicennia schaue- } \\
\text { riana } \\
\text { (dominant) }\end{array}$ & & $\begin{array}{c}\text { Type } 2 \\
(31,49,52)\end{array}$ & $\begin{array}{l}\text { Type } 9 \\
(46,47)\end{array}$ & & \\
\hline $\begin{array}{l}\text { Laguncularia } \\
\text { racemosa } \\
\text { (dominant or } \\
\text { monospecific) }\end{array}$ & & & $\begin{array}{l}\text { Type } 4 \\
(4,11)\end{array}$ & & $\begin{array}{c}\text { Type } 10 \\
(6,7)\end{array}$ \\
\hline Mixed Forests & & & $\begin{array}{c}\text { Type } 5 \\
(1,2)\end{array}$ & $\begin{array}{c}\text { Type } 8 \\
(10,32,44, \\
45)\end{array}$ & $\begin{array}{c}\text { Type } 12 \\
(17)\end{array}$ \\
\hline
\end{tabular}

Source: Adapted from Pellegrini et al. (2009).

Notes:

$\mathrm{DBH}$ - Diameter at breast height, by convention 1.3 meters from the ground.

The numbers in parentheses indicate the sampling stations.

The dominance of a given species in the forest is based on the contribution in the basal area of the species, which represents the area of trunks per area of forest. 
Recognizing that the vulnerabilities of the systems, whether natural or social, are determined by three components: sensitivity (reaction to a given tensor), susceptibility (degree of exposure to risk) and resilience (ability to respond to the materialization of risk) (KLEIN; NICHOLLS, 1999; ADGER, 2006), the referred types of forests identified for the Garapuá region were used as a reference to determine the degree of vulnerability of these forests to oil spills, considering the installation of an exploration/production gas platform off the coast of Tinharé. Therefore, each forest was classified according to its sensitivity, susceptibility, and resilience to oil contamination (table 2).

Table 2 - Vulnerability levels of the Structural Types of mangrove forests from Garapuá (Bahia, Brazil).

\begin{tabular}{|l|l|l|l|l|}
\hline $\begin{array}{l}\text { Structural } \\
\text { Type }\end{array}$ & Sensitivity & $\begin{array}{l}\text { Susceptibi- } \\
\text { lity }\end{array}$ & Resilience & Vulnerability \\
\hline $\mathbf{1}$ & Medium & High & High & Medium \\
\hline $\mathbf{2}$ & Low & High & High & Medium \\
\hline $\mathbf{3}$ & Low & High & High & Medium \\
\hline $\mathbf{4}$ & High & Low & Low & High \\
\hline $\mathbf{5}$ & Medium & High & High & Medium \\
\hline $\mathbf{6}$ & Medium & Medium & Medium & Medium \\
\hline $\mathbf{7}$ & Low & High & Medium & High \\
\hline $\mathbf{8}$ & High & Low & Low & High \\
\hline $\mathbf{9}$ & High & Medium & Medium & High \\
\hline 10 & High & Low & Low & High \\
\hline $\mathbf{1 1}$ & High & Medium & Low & High \\
\hline $\mathbf{1 2}$ & High & Low & Low & High \\
\hline
\end{tabular}

Source: Adapted from Pellegrini et al. (2009)

The sensitivity analysis of mangroves considered the level of natural stress to which forests are subjected. Even though mangroves need saltwater for their occurrence because, in this way they exclude species not adapted to the presence of salts from the environment, mangrove species are considered facultative halophytes. In other words, the presence of saltwater plays a significant role in the competitive exclusion of nonhalophyte species. However, even the mangrove species, despite being adapted to the saline environment, are subjected to physiological stress, considering that they need to spend energy to exclude salts and obtain water (BALL, 1980).

The susceptibility of mangrove forests to oil reflects the probability that these forests being affected by oil, which is related not only to the possibility of oil reaching the region 
but, above all, to impact each forest zone in relation to its position and topography, which depends on the tide conditions at the time the area is reached.

Thus, when analyzing the structural types of mangrove forests, as well as the salinity values of the interstitial water (table 3), we observe that the forests with the highest salinity have, in general, low and intermediate structural development, are located in the innermost parts of mangroves, with low tidal flooding frequency, thus characterizing forests subjected to physiological stress, which would be more sensitive to the additional impacts associated with contamination by oil. Such pattern of reduction in the structural development of mangrove forests submitted to low flood frequency by tides and higher salinity is described and analyzed by Soares et al. (2017).

Finally, for the categorization of mangrove forests, the following were considered: regarding resilience, geomorphological characteristics, the frequency of tidal inundation and exposure to tidal energy as proposed by Soares (2002) and Soares et al. (2003). In this sense, it can be said that the resilience of mangrove forests to contamination by oil and oil products depends, in the first instance, on the frequency of flooding by the tides, because the physical action of "washing" contaminated areas is crucial for the maintenance of microbial processes of decomposition of petroleum hydrocarbons (GETTER et al., 1984).

Thus, the analysis of the resilience of mangrove forests to oil contamination considered the crossing of information on phytosociological characterization (types of mangrove forests), the frequency of flooding by tides and the salinity of interstitial water. This analysis also considered the assumption that naturally more stressed forests and mangrove forests subjected to less flooding by tides have less capacity to react to contamination by oil. 
Table 3 - Mean values of interstitial water salinity in the mangrove forests of Garapuá (Bahia, Brazil), grouped according to structural types and positioning/ topography (physiognomy).

\begin{tabular}{|l|l|l|l|}
\hline $\begin{array}{l}\text { Structural } \\
\text { Type }\end{array}$ & Station & $\begin{array}{l}\text { Physiog- } \\
\text { nomy }\end{array}$ & $\begin{array}{l}\text { Interstitial } \\
\text { Salinity }\end{array}$ \\
\hline
\end{tabular}

\begin{tabular}{|l|l|l|l|}
\hline $\begin{array}{l}\text { Structural } \\
\text { Type }\end{array}$ & Station & $\begin{array}{l}\text { Physiog- } \\
\text { nomy }\end{array}$ & $\begin{array}{l}\text { Inters- } \\
\text { titial } \\
\text { Salinity }\end{array}$ \\
\hline
\end{tabular}




\begin{tabular}{|c|c|c|c|}
\hline \multirow{5}{*}{ Type 1} & 12 & $\begin{array}{l}\text { Interme- } \\
\text { diary }\end{array}$ & $36.0 \pm 0.0$ \\
\hline & 13 & Transition & - \\
\hline & 21 & $\begin{array}{l}\text { Interme- } \\
\text { diary }\end{array}$ & - \\
\hline & 35 & $\begin{array}{l}\text { Interme- } \\
\text { diary }\end{array}$ & - \\
\hline & 34 & Fringe & $35.0 \pm 0.0$ \\
\hline \multirow{3}{*}{ Type 2} & 31 & Fringe & $35.0 \pm 0.0$ \\
\hline & 49 & Fringe & $35.3 \pm 0.6$ \\
\hline & 52 & Fringe & $35.0 \pm 0.0$ \\
\hline \multirow{15}{*}{ Type 3} & 09 & Transition & $37.0 \pm 1.0$ \\
\hline & 18 & $\begin{array}{l}\text { Interme- } \\
\text { diary }\end{array}$ & $36.0 \pm 0.0$ \\
\hline & 22 & $\begin{array}{l}\text { Interme- } \\
\text { diary }\end{array}$ & $35.0 \pm 0.0$ \\
\hline & 26 & $\begin{array}{l}\text { Interme- } \\
\text { diary }\end{array}$ & $36.0 \pm 0.0$ \\
\hline & 29 & $\begin{array}{l}\text { Interme- } \\
\text { diary }\end{array}$ & $35.0 \pm 0.0$ \\
\hline & 36 & Fringe & $35.0 \pm 0.0$ \\
\hline & 39 & $\begin{array}{l}\text { Interme- } \\
\text { diary }\end{array}$ & - \\
\hline & 40 & Fringe & $36.0 \pm 0.0$ \\
\hline & 05 & Transition & $35.0 \pm 0.0$ \\
\hline & 08 & Fringe & $36.0 \pm 0.0$ \\
\hline & 20 & $\begin{array}{l}\text { Interme- } \\
\text { diary }\end{array}$ & $35.0 \pm 0.0$ \\
\hline & 30 & Fringe & $35.3 \pm 0.6$ \\
\hline & 48 & Transition & $35.0+0.0$ \\
\hline & 50 & Transition & $34.0 \pm 1.0$ \\
\hline & 51 & Transition & $31.0 \pm 0.0$ \\
\hline \multirow[b]{2}{*}{ Type 4} & 04 & Transition & - \\
\hline & 11 & Fringe & $41.0 \pm 1.7$ \\
\hline
\end{tabular}

\begin{tabular}{|c|c|c|c|}
\hline \multirow{2}{*}{ Type 5} & 01 & Fringe & $35.0 \pm 0.0$ \\
\hline & 02 & Fringe & $36.0 \pm 1.0$ \\
\hline \multirow{9}{*}{ Type 6} & 14 & $\begin{array}{l}\text { Interme- } \\
\text { diary }\end{array}$ & $37.0 \pm 1.0$ \\
\hline & 15 & $\begin{array}{l}\text { Interme- } \\
\text { diary }\end{array}$ & $41.0 \pm 3.0$ \\
\hline & 19 & $\begin{array}{l}\text { Interme- } \\
\text { diary }\end{array}$ & $36.0 \pm 0.0$ \\
\hline & 23 & $\begin{array}{l}\text { Interme- } \\
\text { diary }\end{array}$ & $38.0 \pm 2.0$ \\
\hline & 25 & Transition & $34.7 \pm 3.1$ \\
\hline & 27 & $\begin{array}{l}\text { Interme- } \\
\text { diary }\end{array}$ & $35.3 \pm 0.6$ \\
\hline & 28 & $\begin{array}{l}\text { Interme- } \\
\text { diary }\end{array}$ & $36.0 \pm 0.0$ \\
\hline & 38 & $\begin{array}{l}\text { Interme- } \\
\text { diary }\end{array}$ & - \\
\hline & 42 & $\begin{array}{l}\text { Interme- } \\
\text { diary }\end{array}$ & - \\
\hline \multirow{4}{*}{ Type 7} & 37 & Transition & - \\
\hline & 41 & Fringe & $36.0 \pm 0.0$ \\
\hline & 43 & Fringe & - \\
\hline & 03 & Fringe & $35.3 \pm 0.6$ \\
\hline \multirow{4}{*}{ Type 8} & 10 & Fringe & $42.3 \pm 3.2$ \\
\hline & 32 & Transition & - \\
\hline & 44 & Fringe & $34.7 \pm 0.6$ \\
\hline & 45 & Transition & $30.7 \pm 2.3$ \\
\hline \multirow{2}{*}{ Type 9} & 46 & Fringe & $34.0 \pm 0.0$ \\
\hline & 47 & Fringe & $33.0 \pm 1.7$ \\
\hline \multirow{2}{*}{ Type 10} & 06 & Transition & - \\
\hline & 07 & Transition & $41.7 \pm 0.6$ \\
\hline \multirow{3}{*}{ Type 11} & 16 & Transition & $46.0 \pm 1.7$ \\
\hline & 33 & $\begin{array}{l}\text { Interme- } \\
\text { diary }\end{array}$ & $35.0 \pm 0.0$ \\
\hline & 24 & Transition & $44.0 \pm 0.0$ \\
\hline Type 12 & 17 & Transition & $51.0 \pm 4.0$ \\
\hline
\end{tabular}

Source: The author, 2019 
Notes:

Fringe - forests in contact with the water body and daily flooded by the tides.

Intermediary - forests located in the interior portion of the system and subjected to less tidal flooding frequency than fringe forests.

Transition - forests located in the transition to the mainland and subjected to less frequency of tidal flooding of the entire forest system.

For a description of the structural types, see Table 1

The oil industry and the "tensioning" of fishermen/womem shellfish gatherers of Garapuá

In addition to the aspects linked to the mangroves, given that the mangrove forests of the eastern portion have an intrinsic vulnerability component to their existence, due to exposure to the open sea that requires the protection of reef formations for their maintenance, and to the different levels of vulnerability between the various portions of the forest, as the trees in the middle portion of the forest do not present structural adaptations/responses to the physical stress that stresses the fringe zone (more exposed to the action of winds and waves), the coastal ecosystems existing on Tinharé island are pressured by factors such as occupation pressure related to real estate speculation, population growth and contamination by pollutants. As these factors occur on ever smaller time scales and ever more comprehensive spatial scales, the resulting vulnerability tends to become more serious.

Regarding the social vulnerability of the Garapuá village, their emergence occurs when different social indicators are considered. Concerning education, the municipal network only offers Elementary Education and Youth and Adult Education - "EJA" (in 2010, there were 45 students enrolled in this type of education). The unavailability of high school provision in Garapuá village meant that young people had to travel $20 \mathrm{~km}$ to Gamboa village, which excluded much school-aged youth from the classrooms and left them with no better prospects for life. In 2010, the municipal government changed this situation with the enrollment of high school students at the local municipal school, which started to function as an extension of the headquarters located in Cairu. In parallel, scholarships and free transportation to Gamboa were made available to members of the community who wished to attend higher education courses in Primary Education, Languages and Administrative Management.

In the health area, the village lacks hospital and emergency structure and the local health care unit does not have permanent medical staff, receiving a biweekly visit from a general practitioner, a dentist, and a gynecologist. Social vulnerability is compounded by the lack of specialist doctors, especially pediatricians, whose consultations are held weekly in Cairu, without the support of municipal transport. Data presented by Icó (2007) record that $40 \%$ of families resort to home health treatments, which was proven in the field surveys on the knowledge of the populations about medicinal herbs used to cure toothache, 
belly and head pains, infections of the female reproductive system, pneumonia, flu etc.

Another element that points to the social vulnerability of Garapuá village is about housing. Because it is confined between large farms, its expansion does not keep pace with population growth. It is common to find houses inhabited by more than one family and, in $55 \%$ of the cases (ICÓ, 2007), with more than seven people in limited space and without privacy.

Regarding public infrastructure, we also highlight: (i) the inadequate transport network with unpaved roads and maritime/estuarine transport depending on sea and tidal conditions; (ii) the precariousness of basic sanitation with the absence of sewage treatment (95\% of the waste is drained through septic tanks, compromising the groundwater, according to Icó, 2007); (iii) the inefficient pre-treatment of water from the Garapuá lagoon $(70 \%)$ and artesian wells (30\%) to supply the village, with consequences for public health; (iv) the inadequate disposal of solid waste in landfills.

Other determinant aspects of social vulnerability, explained in the testimonies of the sixty-four social actors, relate to deficiencies in the field of culture, popular participation, and alternative productive activities. Regarding this last aspect, we emphasize the lack of qualified local labour that catalyzes insertion in the development of new productive alternatives, reflecting on the difficulty of acquiring material and cultural goods and exposure to social risks (vulnerability to drugs, for example); the drop in the fisherman's family income due to the scarcity of fish, the result of overfishing, environmental deterioration and the difficulty in obtaining more sophisticated salvage equipment and more suitable vessels for carrying out the activity on the high seas; in the fragility of the local community organization, which is expressed in the lack of mechanisms to solve everyday problems, evidencing a community disarticulation and generation of conflicts in the process of recognition and respect to differences. This perception, which can be reflected in aspects of immobility in the face of environmental impact issues, also represents an element of the fragility of the social web and, therefore, of social vulnerability.

In this context, families that depend on mangrove resources, as shellfish gatherers, are generally the most vulnerable, as they present characteristics of social exclusion even more severe than those of the community as a whole, in terms of low education, health problems related to working conditions, living with precarious basic sanitation, in addition to being subject to the action of intermediaries that limit the possibility of changing this social framework.

With the advent of the oil industry in the region, social and environmental vulnerabilities have become patent interwoven and have been potentialized in their structural dimensions, since industrial/technological risks are associated with the production, transport and storage of dangerous and/or toxic products (VEYRET; RICHEMOND, 2007).

The perceptions of these risks by the population of Garapuá are associated with the production and transport of oil and its derivatives. In fact, the main product is natural gas (with a portion of condensate) associated with a residual volume of oil. This association is probably related to oil spill and fish mortality events that occurred in the past and linked to the intense passage of oil vessels along the coast, mainly towards the facilities 
located in the Todos os Santos Bay, Salvador (SILVA; NASCIMENTO; REBOUÇAS, 2009; REZENDE, 2010).

Serrão et al. (2009) briefly present the impacts of oil activity as a result of: "i) increase in the immigration rate and change in land use and occupation patterns; ii) marine and coastal environmental degradation; iii) accidents with oil spills at sea; iv) restriction and exclusion of marine areas used by other economic activities, mainly navigation and artisanal fishing; and v) changing on the behavior of marine species due to the presence of physical structures, such as platforms and pipelines". From the enumeration explained by the authors above, the interrelation between industrial/technological risks and socioenvironmental vulnerability becomes evident.

In the case of Garapuá, the interference of the oil industry in daily life started even before the arrival of the Platform, with the presence of technicians from the most varied academic backgrounds (engineers, oceanographers, biologists, sociologists, geographers, geologists, etc.) to the area of influence of the activity to prepare two hundred and nine (209) surveys and previous studies for the implementation of this Platform.

Later, when seismic surveys were carried out, artisanal shoreline fisherwomen reported tremors observed during their mangrove shellfish gathering practices, relating them to the high pressure compressed air "shots", characteristic of these surveys. According to these women, on the days when the tremors occurred, the "Lambretas" migrated to greater depths, making the collection work more difficult.

Another aspect of the influence of activity on the daily lives of the inhabitants of Garapuá occurred when tests were carried out with gas flaring on the offshore platform. The light from the sea combustion reached the coast, illuminating the contours of the mangrove forest. Bearing in mind that the tests were carried out, in part, during the reproduction period of the crabs (commonly known as crab walking period - "andada"), IBAMA's mediation was necessary to suspend them, to minimize the possible impacts of excessive lighting on the animals' movement.

During the initial period of implementation of the Platform, Petrobras (The Brazilian Oil Company) developed the Integrated Program for Productive Projects for Social and Environmental Development with communities in the area of direct influence of the Manati Project - PIPP, within the scope of the Natural Gas Production and Flow System of Manati Field implemented by the Manati Consortium (Petrobras et al., 2006). The implementation of this program was justified by the need to carry out measures to compensate the tourist and fishing sectors of Garapuá village, considering the potential impacts of the activity of the production and flow system of Manati Field in the region of Southern of Bahia.

In an attempt to identify the most relevant aspects of the situation of such activities, their strengths and weaknesses, in addition to recognizing the performance of the leading local institutions, suggesting solutions to face the diagnosed problems, diagnostic workshops were held, and participatory projects were developed with social actors of the village (PETROBRAS et al., 2007).

The documents distributed in the meetings held by the professionals of the techni- 
cal coordination of social communication of the project with the population of Garapuá presented, among its objectives, the intention of sensitizing the community to participate in the process of collective construction of the methodological stages of PIPP through the participatory approach, encouraging the formation of management groups in the community and the generation of new knowledge, based on the articulation between technical expertise and community knowledge (PETROBRAS et al., 2006).

The meeting held by the representatives of PIPP to present the Environmental Education Project at the João Evangelista Coutinho Municipal School, in November 2007, intended to negotiate the projects to be implemented in the following two years as a compensatory measure, based on the Rapid Participatory Emancipatory Diagnosis - "DRPE".

Despite the presence of seven artisanal shoreline fisherwomen, among the 25 participants in the community, this group was unable to explain their needs and expectations, confirming the socio-environmental vulnerability and the impossibility, in view of the fragile political capital that it has, to occupy a claiming space in the power field that was being delimited, for not recognizing it as legitimate, as Mellinger and Floriani (2015) stress. This understanding is supported by the analyzes of Carneiro (2005) when he affirms that the field of "environmental policy" has always been dependent on the more general economic and political imperatives that determine the use of natural elements as conditions for the capital accumulation. As a field of power dispute, the field of "environmental policy" presents itself as the locus for processing conflicts over the use of natural elements and conditions, where social actors are accredited to carry out, through "dialogue" and "understanding", the compatibility between "environmental preservation" and "development", advocated by the ideology of sustainable development.

According to Carneiro (2005), the possibilities of consensus are expanded when the field is structured based on relationships that can establish the regular functioning of a mitigation system that translates into the control of discourse production that "carries with it the power to delimit the actors who can legitimately engage in politics and the issues that are subject to debate" (DAVIDSON; FRICKEL, 2004, p. 478 apud, HANNIGAN, 2009, p. 86). Evidencing the molding of the socialization process that is established in the field of technical-legal disputes, the PIPP document (PETROBRAS et al., 2007, p. 1) announces, in its presentation, that it was "possible to involve the target audience in the consensual construction of guiding strategies (...) with technical subsidies and secondary data". This strategy of using community "participation" and seeking consensus to legitimize the capitalist enterprise camouflages interests and hides power asymmetries between those established in the territory and outsiders.

When analyzing the meaning of "participation" in contemporary discourse in Brazil, Dagnino (2004, apud ROMANO; ANDRADE; ANTUNES, 2007) diagnoses two versions that define this concept. First, as a project built around the expansion of citizenship and the deepening of democracy and then relating it to the shrinking of State responsibilities and the progressive withdrawal of the State from its role as guarantor of rights. Thus, the meanings and expressions of participation that emerge rival each other and, although they may present themselves as contradictory, they can occur simultane- 
ously in the perception of different actors interacting in the same spaces. Serrão et al. (2009) corroborate this position by stating that the projects linked to the environmental licensing processes for oil activities in Southern Bahia represent an exceptionally fine limit between emancipatory and supervised actions. Romano et al. (2007) point out that the meanings given by these actors to "participation" in a shared space can describe completely different expectations and involvement, therefore, its definition is a political issue, while logic in dispute in the spaces of participation. For example, this author emphasizes the expression "participation" as an organization and decision making at the local level to generate more self-sufficiency, both the neoliberal type (do it yourself) and the typology of community participation ("from the bottom to up"). The reframing of the concept of participation in the neoliberal perspective allows us to see that the discursive appropriation to which this term has been subjected has contributed to its imprecision, considering that the rhetoric of social participation provides the development of strategies that guarantee the reproduction of power relations (PARAÍSO, 2005). In the same line of interpretation, Rahnema (2000, apud PARAÍSO, 2005) says that the actions called as "participatory", are exhibited in unquestionable forms and even if bring emancipatory elements in the social imaginary, they continue to be guided by relations of tutelage and control, with the legitimization of proposals that establish limits for the performance of local social actors, being redirected to ways often opposite to those initially foreseen in community political projects.

According to Dagnino (2004), it is necessary to analyze the ideologies underlying the projects that guide the elaboration of socioenvironmental actions called "participatory", to elucidate the obstacles experienced in the practices of decision-making processes, to make them effectively democratic. Dagnino et al. (2006) point out that, by reframing the notions of participation, the neoliberal project fulfils the precept of depoliticizing and minimizing political spaces where battles can be fought to promote the constitution of citizens who build their stories.

According to Zhouri and Oliveira (2005), the transformation of social and environmental problems arising from economic projects into technical issues that can be circumvented through the alliance between capital, bureaucracy and science leads to the emptying of the political debate in the field of conflicts over the social appropriation of nature. The scientific posture that transforms the technique into a self-referred, selfregulating system with its logic conceives the instrumental as being able to intervene not only on theories and practices but on social organization.

\section{Socio-environmental vulnerability from an interdisciplinary perspective}

The disputes in the field of power, a minimally structured space for relations and conflict processing, and the constant affirmation of the hegemonic conception of democracy, which seeks to stabilize the controlled tension between democracy and capitalism "by limiting citizen participation, both individual and collective, with the objective of not "overloading" the democratic regime with social demands that may endanger the priority 
of accumulation over social redistribution "(SANTOS, 2003), allow us to glimpse the institutionalizing fragility and the consequent vulnerability of the participation of artisanal shoreline fisherwomen in Garapuá which, in their demands, reveal counter-hegemonic interests and conceptions.

In this same interpretative line, Zborowski and Loureiro (2008) highlight that the analysis of environmental problems at a local scale shows a reality of inequalities and conflicts that are interwoven with it, which involve clashes for social and ideological domination, that is, between hegemonic forces, holders of great economic and political power, and peripheral populations, with little material, symbolic and organizational power to challenge hegemonic forces, even though conflicts are also registered due to cultural shock between different ways of perceiving and appropriating the natural environment.

Although the oil industry is one of the main exponents of the hegemonic developmental discourse, it is not the only economic vector whose interests can intensify aspects of vulnerability observed in small communities along the Brazilian coast and, particularly in Garapuá village. In this sense, more than perceiving and registering the accelerated process of change that these communities are going through, it is important to seek alternative forms of instrumentalization of these populations, so that the democratic debate be established at another level, above all more symmetrical.

The solution of the problem in question is based on the incorporation of the notion of environmental justice into the debate established in the region of Southern Bahia and on the understanding that it presents itself as a reframing of the environmental issue.

Starting from the premise that social injustice and environmental degradation have related roots, the movements for environmental justice propose a change in the correlation of forces in the power field where spaces and interests are disputed over the appropriation of environmental elements to strengthen the groups that have a minor cultural capital in these political arenas to try to avoid or reduce the transfer of environmental development costs to the most socially and economically deprived (ACSELRAD, 2010).

As more vulnerable populations tend to increase the effort to collect "Lambretas" and other biological elements of lesser local economic importance, environmental vulnerability is causally related to social vulnerability. Likewise, the risk of oil spills increase environmental vulnerability and, thus, also increase social vulnerability from the losses that can result in elements from mangrove forests and fishing activities.

It is in this context that we seek to reconnect the concepts that fragment vulnerability into an environmental component (referring to the ecological system) and a social component, from an interdisciplinary perspective so that an analysis of the entire system can emerge under the veil of socio-environmental vulnerability.

From this interdisciplinary perspective, we must recognize that the vulnerability of the Garapuá mangrove forests to contamination by oil increased with the establishment of gas exploration/production activities in the region and an increase in their susceptibility to contamination, considering that the other two components of vulnerability (sensitivity and resilience) remained unchanged. On the other hand, if we consider the relevance of 
shellfish extraction for the survival of the Garapuá community and the socioeconomic context identified in that region, the resilience of that community to changes in the "lambreta"s production chain (in other words, the ability to search for economic production alternatives) is extremely low. Thus, we recognize the high vulnerability of this community to changes in the mangrove ecosystem, when the "lambreta" stocks available for exploration are affected.

The chain of relationships described above forms the basis for the analysis of socioenvironmental vulnerability which, from an interdisciplinary perspective, goes beyond the sum of environmental and social vulnerabilities, recognizing the strong interdependence of these components.

Under the auspices of this approach, it appears that, with the new scenario that presents itself in Garapuá, associated with the insertion of the oil and gas industry in the region, there was an increase in the socio-environmental vulnerability of the mangroveartisanal shoreline fisherwomen/gatherers/fisherman system.

Although the scope of risk perception may have been restricted at first to fishers and forest users, over time, however, it has reached the entire Garapuá community. Even residents who do not perform activities directly linked to fishing or shoreline shellfish gathering, as nursing technicians who live and work in the community, for example, suffer psychologically from the "possibility of a disgrace", in the words of a local artisanal shoreline fisherwoman.

\section{Conclusions}

\section{The interdisciplinary view as an integrated environmental management strategy}

In the perspective of showing that the complexity of the relationships established in coastal communities demands the adoption of interdisciplinary approaches, both for the elaboration of analyzes that aim at understanding complex socioenvironmental systems, as well as for the proposition of mitigating actions that intend to face the identified problems, this article presented the relationship between the oil industry and socio-environmental vulnerability in the mangroves of southern Bahia, emphasizing the view of the observer in the process of defining and analyzing the object studied.

By taking the interdisciplinary methodological approach, the article raises reflections that conceive issues in their complexity and reflect views that can be complemented, representing open processes that are dependent, not only on the observed phenomenon, but also from the perspective of those who observe and, therefore, they cannot be exhausted, even when limited to a space-time frame. In this sense, the observation and interpretation of the problem of the insertion of the Oil and Gas Platform in the Garapuá cove, on the southern coast of Bahia, and the socio-environmental vulnerabilities inflicted on the mangrove and the local population demand analyzes on the social actors who do 
not express their points of view on the dominant technical-scientific language in the field of environmental policy and the non-recognition of local socio-cultural manifestations, given that these invisibilities disadvantage the connection points between the experience accumulated by these actors and the proposal to involve them in the sustainable development process.

Besides that, the existence of a relationship between the disorganization in the provision of information and the mechanisms for reflection on the socio-environmental problems identified in Garapuá village demonstrates that, in this field of power, the neoliberal ideology tends to produce a categorical framework that mitigates the existing conflicts and to perpetuate the structural parameters established in the power relationships. This fact is confirmed by the asymmetries of power formed from the inequalities recognized in the scope of the meetings, which, although they do not prevent the exercise of deliberative freedom, affect the decision-making process, considering that the industrial sector, as well as the public sector representing Union, has greater control and power over the actions of this political instance. The disputes in the field of power, minimally structured space for relations and conflict processing, and the constant affirmation of the hegemonic conception of democracy, which seeks to stabilize the controlled tension between democracy and capitalism "by limiting citizen participation, both individual and collective, with the objective of not "overloading" the democratic regime with social demands that may endanger the priority of accumulation over social redistribution "(SANTOS, 2003), allow us to glimpse the institutional fragility and the consequent vulnerability of the participation of artisanal shoreline fisherwomen in Garapuá which, in their demands, reveal counter-hegemonic interests and conceptions.

Expanding the analysis beyond Petrobras' current production, the insertion of the oil industry in the coastal region adjacent to Garapuá necessarily represents an increase in the environmental risks to which coastal ecosystems in this region are subjected and, in parallel, an increase in local social vulnerability. Under penalty of under-dimensioning the impacts related to the risks inherent to the oil industry, considerations regarding Garapuás socio-environmental vulnerability, which assess environmental, social, economic and cultural aspects in a fragmented way, expose a significant portion of the local population to conditions of exclusion even higher than those established so far.

In this sense, the development of interdisciplinary studies and research represents an essential tool as the training of managers, professionals and local social actors with a view to the totality strengthens the debate in different segments of society (companies, environmental agencies, non-governmental organizations, universities, communities, etc.) and, consequently, tends to favour the transformation of the socio-environmental reality experienced by social groups deprived of decision-making power. McFadden et al. (2007) draw attention to the fact that studies related to vulnerability, which are necessarily interdisciplinary, are only carried out when the scientific language can be translated and incorporated into coastal management strategies, plans and policies, as the lack of a totalizing vision represents an obstacle to the development of processes that aim for emancipation, as well as the implementation of practices that enable the integrated 
management of the environment.

\section{Referências}

ACSELRAD, H. Ambientalização das lutas sociais - o caso do movimento por justiça ambiental. Estudos Avançados, v.24, n. 68, p. 103-119, 2010.

ADGER, W. N. Vulnerability. Global Environmental Change, v. 16, n. 3, p. 268-281, 2006.

ALVARENGA, A. T.; PHILlIPI Jr., A.; SOMMERMAN, A.; SOUZA, A. M.; FERNANDES, V. Histórico, fundamentos filosóficos e teórico-metodológicos da interdisciplinaridade. In: PHILLIPI Jr., A.; Silva Neto, A. J. (Ed.). Interdisciplinaridade em Ciência, Tecnologia e Inovação. Barueri: Manole, 2011, p. 3-68.

BALL, M. C. Patterns of secondary succession in a mangrove forest of southern Florida. Oecologia, v. 44, n. 2, p. 226-235, 1980.

BRANDÃO, C. R. (org.). Pesquisa participante. São Paulo: Brasiliense, 1982.

CARNEIRO, E. J. A oligarquização da política ambiental mineira. In: ZHOURI, A.; LASCHEFSKI, K.; PEREIRA, D. B. (Org.). A insustentável leveza da política ambiental - desenvolvimento e conflitos socioambientais. Belo Horizonte: Autêntica, 2005. p. 65-88.

CINTRÓN, G.; SCHAEFFER-NOVELLI, Y. Methods for studying mangrove structure. In: Snedaker, S. C.; Snedaker, J. G. (Ed.). The mangrove ecosystem: Research methods. Bungay, United Kingdom: UNESCO, 1984. p. 91-113.

DAGNINO, E. (org.). Anos noventa: política e sociedade no Brasil. São Paulo: Brasiliense, 2004.

DAGNINO, E.; OLVERA, A. J.; PANFICHI, A. A disputa pela construção democrática na América Latina. São Paulo: Paz e Terra, 2006.

DAVIDSON, D. J.; FRICKEL, S. Understanding environmental governance: a critical review. Organization \& Environment, v. 17, n. 4, p. 471-492, 2004.

GETTER, C. D.; CINTRON, G.; DICKS, B.; LEWIS, R. R.; SENECA, E. D. The recovery and restoration of saltmarshes and mangrove following an oil spill. In: Cairns Jr.,J.; Buikema Jr., A.L. (Ed.). Restoration of habitats impacted by oil spills. Boston: Butterworth. 1984, p. 65-113.

GIL, R. Análise de discurso. In: BAUER, M.; GASKELL, G. Pesquisa qualitativa com texto, imagem e som: um manual prático. Petrópolis: Vozes, 2002.

GIL, A. C. Métodos e técnicas de entrevista social. São Paulo: Atlas, 1999.

ICÓ, I. Desenvolvimento local: adaptação ou contestação? As realidades de Garapuá e Barra dos Carvalhos - BA. Dissertação de Mestrado. Salvador: Núcleo de Pós-Graduação em Admi- 
nistração/UFBA, 2007.

HANNIGAN, J. Sociologia Ambiental. Petrópolis: Vozes, 2009.

KLEIN, R.; NICHOLLS, R. Assessment of Coastal Vulnerability to Climate Change. Ambio, v. 28, n. 2, p. 182-187, 1999.

KOSIK, K. Dialética do concreto. Rio de Janeiro: Paz e Terra, 1976.

LITTLE, P. E. Ecologia Política como etnografia: um guia teórico e metodológico. Horizontes Antropológicos, ano 12, n. 25, p. 85-103, jan/jun, 2006.

MARTINS, G. de A.; THEÓPHILO, C. R. Metodologia da investigação científica para Ciências Sociais Aplicadas. São Paulo: Atlas, 2009.

MCFADDEN, L.; PENNING-ROWSELL, E.; NICHOLLS, R. Setting the Parameters: A Framework for Developing Cross-Cutting Perspectives of Vulnerability for Coastal Zone Management. In: MCFADDEN, L.; PENNING-ROWSELL, E.; NICHOLLS, R. (Ed.). Managing Coastal Vulnerability. Oxford: Elsevier, 2007.

MELLINGER, L.; FLORIANI, D. Participação democrática dos bens naturais comuns e populações nativas no litoral sul do Paraná. Ambiente e Sociedade. São Paulo. V.XVIII, n. 2. Abr-jun 2015.

MORIN, E. Introdução ao pensamento complexo. Porto Alegre: Sulina, 2007.

PARAÍSO, L. B. Dilemas da participação na gestão de unidades de conservação: a experiência do projeto Doces Matas na RPPN Mata do Sossego. In: ZHOURI, A.; LASCHEFSKI, K.; PEREIRA, D. B. (Org.). A insustentável leveza da política ambiental - desenvolvimento e conflitos socioambientais. Belo Horizonte: Autêntica, 2005. p. 143-168.

PELLEGRINI, J. A. C. Vulnerabilidade socioambiental dos manguezais de Garapuá, Cairu/ BA frente à inserção da indústria petroleira. Rio de Janeiro: UERJ, 2010. Tese (Doutorado em Meio Ambiente). PPGMA - Universidade do Estado do Rio de Janeiro, 2010.

PELlEGRINI, J. A. C.; SOARES, M. L. G.; CHAVES, F. O.; ESTRADA, G. C. D.; CAVALCANTI, V. F. A Method for the Classification of Mangrove Forests and Sensitivity/ Vulnerability Analysis. Journal of Coastal Research, v. SI 56, p. 443-447. 2009.

PETROBRAS; QUEIROZ GALVÃO; NORSE ENERGY. Programa Integrado de Projetos Produtivos de Desenvolvimento Sócio-Ambiental com Comunidades da Área de Influência Direta do Projeto Manati. Volume Único, rev 03. Novembro, 2006.

PETROBRAS; QUEIROZ GALVÃO; NORSE ENERGY. Projeto Participativo Compensatório de Guarapuá, Ilha de Tinharé, Município de Cairu-BA (PIPP/Manati). Sistema de produção e escoamento de gás natural do Campo de Manati. Outubro, 2007.

RAHNEMA, M. Participação. In: SACHS, W. (org.). Dicionário do desenvolvimento. Petró- 
polis: Vozes, 2000.

REZENDE, L. F. Dinâmica em múltiplas escalas na Margem Continental Leste Brasileira. Aveiro: UA, 2010. Tese (Doutorado em Física). Universidade de Aveiro, Portugal, 2010.

ROMANO, J.; ANDRADE, M. P.; ANTUNES, M. Olhar crítico sobre participação e cidadania: a construção de uma governança democrática e participativa a partir do local. São Paulo: Expressão Popular, 2007.

SANTOS, B. S. Democratizar a democracia: os caminhos da democracia participativa. Rio de Janeiro: Civilização Brasileira, 2003.

SERRÃO, M. A.; WALTER, T.; VICENTE, A. S. Educação Ambiental no licenciamento: duas experiências no litoral baiano. In: LOUREIRO, C. F. B. (Org.) Educação Ambiental no contexto de medidas mitigadoras e compensatórias de impactos ambientais: a perspectiva do licenciamento. Salvador: IMA, 2009.

SILVA, I. R.; NASCIMENTO, H. M.; REBOUÇAS, R. C. Avaliação da sensibilidade ambiental das praias localizadas no arquipélago Tinharé/Boipeba, litoral sul do estado da Bahia. São Paulo, UNESP, Geociências, v. 28, n. 2, p. 193-201, 2009.

SOARES, M.L.G. (coord.). Diagnóstico de danos causados aos manguezais da Baía de Guanabara pelo derramamento de óleo ocorrido em janeiro de 2000. Rio de Janeiro: Secretaria de Estado de Meio Ambiente e Desenvolvimento Sustentável, Relatório não publicado, 2002.

SOARES, M. L. G.; CHAVES, F. O.; CORRÊA, F. M.; SILVA JÚNIOR, C. M. G. Diversidade Estrutural de Bosques de Mangue e sua Relação com Distúrbios de Origem Antrópica: o Caso da Baía de Guanabara (Rio de Janeiro). Anuário do Instituto de Geociências - UFRJ, v. 26, p. 101-116, 2003.

SOARES, M. L. G.; CHAVES, F. O.; ESTRADA, G. C. D.; FERNANDEZ, V. Mangrove forests associated with salt flats: a case study from southeast Brazil. Brazilian Journal of Oceanography, v. 65, n. 2, p. 102-115, 2017.

STODDART, D. R. Mangroves as successional stages, inner reefs of the northern Great Barrier Reef. Journal of Biogeography, v. 7, p. 269-284, 1980.

VEYRET, Y.; RICHEMOND, N. M. Representação, gestão e expressão especial do risco. In: Veyret, Y.(org.). Os Riscos: o homem como agressor e vítima do meio ambiente. São Paulo: Contexto, 2007.

ZBOROWSKI, M. B.; LOUREIRO, C. F. B. Conflitos Ambientais na Baía de Sepetiba: o caso dos pescadores artesanais frente ao processo de implantação do complexo siderúrgico da Companhia Siderúrgica do Atlântico - ThyssenKrupp CSA. In: IV Encontro Nacional da Associação Nacional de Pós-Graduação e Pesquisa em Ambiente e Sociedade-ANPPAS, Brasília (DF). Anais... ANPPAS, 2008.

ZHOURI, A.; OLIVEIRA, R. Paisagens industriais e desterritorialização de populações locais: 
conflitos socioambientais em projetos hidrelétricos. In: ZHOURI, A.; LASCHEFSKI, K.; PEREIRA, D. B. (Org.). A insustentável leveza da política ambiental - desenvolvimento e conflitos socioambientais. Belo Horizonte: Autêntica, 2005. p. 49-64. 
Julio Augusto de Castro Pellegrini

$\square$ julio@prooceano.com.br

ORCiD: https://orcid.org/0000-0002-1695-1113
Submitted on: 29/07/2018

Accepted on: 24/03/2020

2020;23:e01753

\title{
Elza Maria Neffa Vieira de Castro
}

ఐelzaneffa@gmail.com

ORCiD: https://orcid.org/0000-0003-1878-0263

Krishna Neffa Vieira de Castro

$\square$ krishnaneffa@gmail.com

ORCiD: https://orcid.org/0000-0001-5109-288X

\author{
Mário Luiz Gomes Soares \\ ఐmariolgs@uerj.br \\ ORCiD: https://orcid.org/0000-0002-3312-7257
}

How to cite: PELLEGRINI, J.A.C.; CASTRO, E.M.N.V.; CASTRO, K.N.; SOARES, M.L.G.. Socio-environmental tensioning in coastal communities: an interdisciplinary study in the mangroves of southern Bahia. Ambiente \& Sociedade. São Paulo, v. 23, p. $1-23,2020$. 


\title{
Tensionamentos socioambientais em comunidades costeiras: um estudo interdisciplinar nos manguezais do sul da Bahia
}

\author{
Júlio Augusto de Castro Pellegrini \\ Elza Maria Neffa Vieira de Castro \\ Krishna Neffa Vieira de Castro \\ Mário Luiz Gomes Soares
}

São Paulo. Vol. 23, 2020

Artigo Original
Resumo: Esse artigo analisa as conexões entre a vulnerabilidade ambiental das florestas de mangue da enseada de Garapuá (Bahia) e a vulnerabilidade social de marisqueiras e pescadores, a partir dos tensionamentos infligidos com a inserção da indústria petrolífera. Sob a perspectiva interdisciplinar, apresenta a interpretação de fenômenos complexos e de gestão integrada do ambiente incorporando a abertura do espírito humano para a visão da totalidade. A apreensão da lógica dialética dos processos socioambientais locais deu-se com base na caracterização dos manguezais, utilizando-se de métodos da pesquisa quantitativa e na integração com o processo investigatório via observações de campo e entrevistas semi-estruturadas, na ótica da abordagem qualitativa. Assim, o artigo pretendeu demonstrar que a análise interdisciplinar fortalece o debate em distintos segmentos da sociedade (empresas, órgãos ambientais, organizações não-governamentais, universidades, comunidades etc) e, consequentemente, tende a favorecer a transformação da realidade socioambiental vivenciada por grupos sociais com menor poder de decisão.

Palavras-chave: Manguezal; Fitossociologia; Indústria de petróleo; Vulnerabilidade socioambiental; Interdisciplinaridade.

Como citar: PELLEGRINI, J.A.C.; CASTRO, E.M.N.V.; CASTRO, K.N.; SOARES, M.L.G. Tensionamentos socioambientais em comunidades costeiras: um estudo interdisciplinar nos manguezais do sul da Bahia. Ambiente \& Sociedade. São Paulo, v. 23, p. 1-23, 2020. 


\title{
Tensión socioambiental en comunidades costeras: un estudio interdisciplinario en los manglares del sur de Bahía
}

\author{
Júlio Augusto de Castro Pellegrini \\ Elza Maria Neffa Vieira de Castro \\ Krishna Neffa Vieira de Castro \\ Mário Luiz Gomes Soares
}

São Paulo. Vol. 23, 2020

Artículo original
Resumen: Este artículo analiza las conexiones entre vulnerabilidad ambiental de los manglares de Garapuá (Bahía) y la vulnerabilidad social de marisqueros y pescadores, a partir de tensiones infligidas con la inserción de la industria petrolera. Desde una perspectiva interdisciplinaria, presenta la interpretación de los fenómenos complejos y la gestión integrada del entorno, incorporando la apertura del espíritu humano a la visión de la totalidad. La aprehensión de la lógica dialéctica de los procesos socioambientales locales se basó en la caracterización de los manglares, utilizando métodos de investigación cuantitativa y la integración con el proceso de investigación a través de observaciones de campo y entrevistas semiestructuradas, desde el punto de vista del enfoque cualitativo. El artículo tuvo como objetivo demostrar que el análisis interdisciplinario fortalece el debate en diferentes segmentos de la sociedad y tiende a favorecer la transformación de la realidad socioambiental experimentada por grupos sociales sin poder de decisión.

Palabras-clave: Manglares; Fitosociología; Indústria del petróleo; Vulnerabilidad socioambiental; Interdisciplinariedad.

Como citar: PELLEGRINI, J.A.C.; CASTRO, E.M.N.V.; CASTRO, K.N.; SOARES, M.L.G. Tensión socioambiental en comunidades costeras: un estudio interdisciplinario en los manglares del sur de Bahía. Ambiente \& Sociedade. São Paulo, v. 23, p. 1-23, 2020. 